\title{
A New Acetylenic Compound from the Rhizomes of Atractylodes chinensis and Its Absolute Configuration
}

\author{
Yoichiro Nakai, * Iwao Sakakibara, Kazuhiro Hirakura, Susumu Terabayashi, and Shuichi Takeda \\ Pharmacognosy \& Medicinal Resources Research Department, Central Research Laboratories, Tsumura \& Co.; 3586 \\ Yoshiwara, Ami-machi, Inashiki-gun, Ibaraki 300-1192, Japan. \\ Received June 6, 2005; accepted September 28, 2005; published online September 30, 2005
}

A new acetylenic compound "atractyloyne", $(3 S, 4 E, 6 E, 12 E)$-1-isovaleryloxy-tetradeca-4,6,12-triene-8,10diyne-3,14-diol (1) was isolated from the rhizomes of Atractylodes chinensis (Compositae) together with a known compound $(4 E, 6 E, 12 E)$-3-isovaleryloxy-tetradeca-4,6,12-triene-8,10-diyne-1,14-diol (2). These structures were determined on the basis of the spectroscopic data and chemical evidence, and the absolute configuration of 1 was established by the modified 2-methoxy-2-trifluoromethylphenylacetic acid (MTPA) method.

Key words Atractylodes chinensis; atractyloyne; absolute configuration; modified 2-methoxy-2-trifluoromethylphenylacetic acid (MTPA) method; polyacetylene

The dried rhizomes of Atractylodes chinensis Koidzumi $(A$. chinensis) as well as Atractylodes lancea De CANDolle (A. lancea) have traditionally been used as crude drugs in Japan. Both of them are defined as original plants of "Sojutsu" (Atractylodes Lanceae Rhizome) in Japanese Pharmacopeia, used as diuretic and stomachic. ${ }^{1)}$ In the previous paper, we reported the isolation of several polyacetylenic compounds from the rhizomes of $A$. lancea act as improvement of the delay of gastric emptying. ${ }^{2}$ So far several polyacetylenic compounds from the rhizomes of $A$. lancea, ${ }^{3-6)}$ and also the isolation of three polyacetylenic compounds from the rhizomes of A. chinensis were already reported. ${ }^{7)}$ In this paper, we reported the isolation and the structure determination of a new polyacetylenic compound, named "atractyloyne".

Compound $\mathbf{1}$ was isolated as optically active pale yellow oil, $[\alpha]_{D}+45^{\circ}$ and has the molecular formula $\mathrm{C}_{19} \mathrm{H}_{24} \mathrm{O}_{4}$ based on EI-MS and HR-ESI-MS. The UV spectrum showed typical absorptions at $\lambda_{\max } 336,314295,266$ and $250 \mathrm{~nm}$ for an ene-diyne-diene chromophore. ${ }^{8)}$ The IR spectrum of 1 showed the presence of a conjugated triple bond $\left(2200 \mathrm{~cm}^{-1}\right)$, a conjugated double bond $\left(1636 \mathrm{~cm}^{-1}\right)$, an ester carbonyl bond $\left(1732 \mathrm{~cm}^{-1}\right)$ and a hydroxyl group $\left(3402 \mathrm{~cm}^{-1}\right)$. The ${ }^{1} \mathrm{H}-\mathrm{NMR}$ spectrum of 1 showed olefinic protons assignable to three trans double bonds at $\delta 5.86(1 \mathrm{H}$, d, $\left.J=15 \mathrm{~Hz}, \mathrm{C}_{4}-\mathrm{H}\right), 6.33\left(1 \mathrm{H}, \mathrm{dd}, J=15,11 \mathrm{~Hz}, \mathrm{C}_{5}-\mathrm{H}\right), 6.70$ $\left(1 \mathrm{H}, \mathrm{dd}, J=15,11 \mathrm{~Hz}, \mathrm{C}_{6}-\mathrm{H}\right), 5.68\left(1 \mathrm{H}, \mathrm{d}, J=15 \mathrm{~Hz}, \mathrm{C}_{7}-\mathrm{H}\right)$, $5.87\left(1 \mathrm{H}, \mathrm{d}, J=16 \mathrm{~Hz}, \mathrm{C}_{12}-\mathrm{H}\right), 6.41\left(1 \mathrm{H}, \mathrm{dt}, J=16,5 \mathrm{~Hz}, \mathrm{C}_{13}-\right.$ $\mathrm{H}$ ), four methylene protons at $\delta 4.14,4.26\left(\right.$ each $1 \mathrm{H}, \mathrm{m}, \mathrm{C}_{1}$ $\mathrm{H}), 1.79-1.93\left(2 \mathrm{H}, \mathrm{m}, \mathrm{C}_{2}-\mathrm{H}\right), 4.26\left(2 \mathrm{H}, \mathrm{m}, \mathrm{C}_{14}-\mathrm{H}\right), 2.20$ $\left(2 \mathrm{H}, \mathrm{d}, J=7 \mathrm{~Hz}, \mathrm{C}_{2},-\mathrm{H}\right)$, and two methyl protons at $\delta 0.96$ $\left(6 \mathrm{H}, \mathrm{d}, J=7 \mathrm{~Hz}, \mathrm{C}_{3^{\prime}-\mathrm{Me}}\right)$, respectively. The ${ }^{13} \mathrm{C}-\mathrm{NMR}$ spectrum of 1 showed a carbonyl carbon at $\delta 173.5$, two methyl carbons at $\delta 22.4$ (two overlapping), four methylene carbons at $\delta 62.7,60.8,43.4,36.1$ and two methine carbons at $\delta 68.9$ and 25.7, respectively. On hydrolysis by acid or boiling water, 1 afforded $(4 E, 6 E, 12 E)$-tetradeca-4,6,12-triene-8,10diyne-1,3,14-triol (3), ${ }^{9,10}$ ) which was identified by ${ }^{1} \mathrm{H}$ - and ${ }^{13} \mathrm{C}$-NMR spectra. In comparison of the ${ }^{13} \mathrm{C}$-NMR spectrum of $\mathbf{1}$ with that of $2,{ }^{6}$ ) isovaleryloxy moiety of $\mathbf{1}$ was attached to $\mathrm{C}_{1}$ hydroxy group. From these data, structure of 1 were determined to be $(4 E, 6 E, 12 E)$-1-isovaleryloxy-tetradeca4,6,12-triene-8,10-diyne-3,14-diol.
In order to determine the absolute configuration at $\mathrm{C}_{3}$ of $\mathbf{1}$, compound 1 was converted into the $S$ - and $R$-2-methoxy-2trifluoromethylphenylacetic acid (MTPA) esters. ${ }^{11,12)}$ The values of $\Delta \delta$ [ $\delta(S$-MTPA ester $)-\delta(R$-MTPA ester) $)$ were shown in Fig. 2. These results suggested that the absolute configuration at $\mathrm{C}_{3}$ of $\mathbf{1}$ is $S$, and the structure of $\mathbf{1}$ was determined to be $(3 S, 4 E, 6 E, 12 E)$-1-isovaleryloxy-tetradeca-4,6,12-triene8,10-diyne-3,14-diol, named "atractyloyne" (Fig. 1).

In this study, a new acetylenic compound $\mathbf{1}$ and a known compound $\mathbf{2}$ were isolated from the rhizomes of $A$. chinensis for the first time to our knowledge. Because the compound 1 was partly converted to $\mathbf{3}$ by hydrolysis, as described above, it was suggested that both $\mathbf{1}$ and $\mathbf{2}$ in the rhizomes were con-

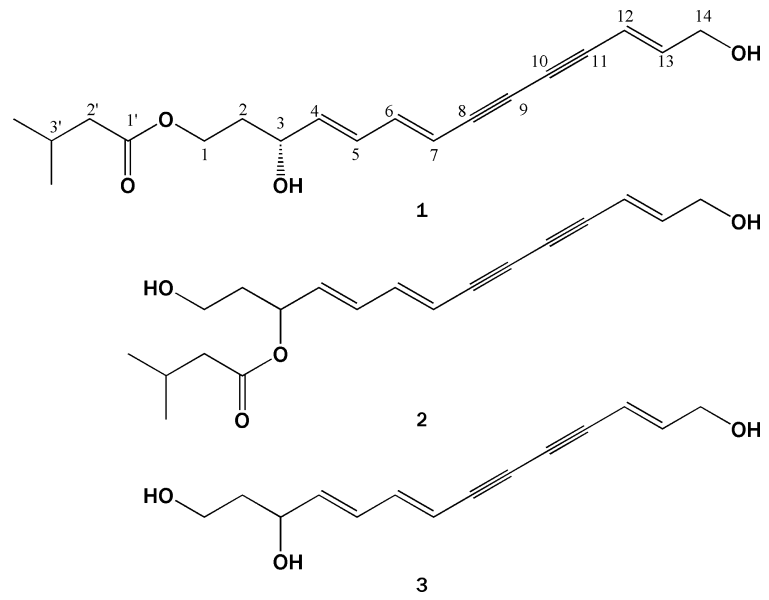

Fig. 1. Structures of Isolated Compounds 1, 2 and Hydrolyte $\mathbf{3}$

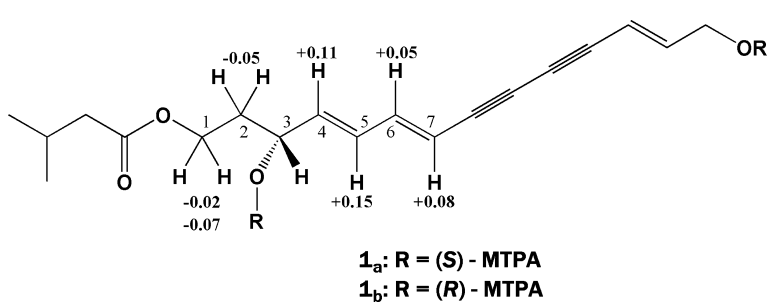

Fig. 2. Chemical Shifts Difference for the $(S)$-MTPA Ester $\left(\mathbf{1}_{\mathrm{a}}\right)$ and $(R)$ MTPA Ester $\left(\mathbf{1}_{\mathbf{b}}\right)$ in ppm 
verted to $\mathbf{3}$ through the boiling water extraction process. Therefore, improving effect of the rhizomes of $A$. chinensis on stomach disorder should consider the amount of $\mathbf{1}$ and $\mathbf{2}$ as well as the amount of bioactive compound $\mathbf{3}$. $^{2)}$

\section{Experimental}

General Experiment Procedures The UV spectrum was obtained with a HITACHI U-3000 spectrophotometer, whereas the IR spectrum was measured with a JASCO FT/IR-8300 spectrometer. Optical rotation was measured with a JASCO DIP-1000 digital polarimeter. The HR-ESI-MS and EIMS were taken on a MICROMASS Q-Tof micro and a KRATOS CONCEPT 1S spectrometer, respectively. The ${ }^{1} \mathrm{H}$ - and ${ }^{13} \mathrm{C}-\mathrm{NMR}$ spectra were measured with a JEOL EX-400 ( $\left({ }^{1} \mathrm{H}-\mathrm{NMR}: 400 \mathrm{MHz},{ }^{13} \mathrm{C}-\mathrm{NMR}: 100 \mathrm{MHz}\right)$ or BRUKER AM-500 ( $\left.{ }^{1} \mathrm{H}-\mathrm{NMR}: 500 \mathrm{MHz},{ }^{13} \mathrm{C}-\mathrm{NMR}: 125 \mathrm{MHz}\right)$ spectrometer with TMS as the internal reference, and chemical shifts are expressed in $\delta$ (ppm).

Crude Drug Material The plant material was purchased in China, and identified using analysis of the internal transcribed spacer of nuclear ribosomal DNA by Ms. M. Shiba in our laboratory. ${ }^{8)}$ A voucher specimen (No. THS-77081) has been deposited in our institute.

Extraction and Isolation Dried, ground rhizomes of the material $(1.0 \mathrm{~kg})$ were extracted with $\mathrm{MeOH}(101)$ under reflux for $2 \mathrm{~h}$. The extract was concentrated under reduced pressure and suspended in water $(500 \mathrm{ml})$. The suspension was extracted with EtOAc $(500 \mathrm{ml} \times 3)$, and the organic layer was concentrated to give the EtOAc fraction $(93 \mathrm{~g})$. The EtOAc fraction was dispersed into $n$-hexane (21) with vigorous stirring followed by filtration to afford the $n$-hexane-insoluble portion $(25 \mathrm{~g})$. Subsequently, the $n$-hexaneinsoluble portion $(20 \mathrm{~g})$ was chromatographed on silica gel $(6 \mathrm{~cm}$ i.d. $\times$ $34 \mathrm{~cm}, 500 \mathrm{~g}$ ) eluted stepwise with a mixture of acetone and benzene $(0: 100 \rightarrow 20: 80)$. The $15 \%$ acetone-benzene eluent was repeatedly subjected to fractionation using a prep ODS-column ( $45 \%$ aqueous $\mathrm{MeOH}$, flow rate $3.5 \mathrm{ml} / \mathrm{min}$, detection at $334 \mathrm{~nm})$ to give $\mathbf{1}$ as a pale yellow oil $(1.27 \mathrm{~g})$ and $\mathbf{2}$ as a pale yellow oil $(0.57 \mathrm{~g})$.

Compound 1: Pale yellow oil; $[\alpha]_{\mathrm{D}}^{22}+45^{\circ}(c=0.139, \mathrm{MeOH})$; UV $\lambda_{\max }$ $\mathrm{nm}(\mathrm{MeOH}, \log \varepsilon): 336$ (4.41), 314 (4.55), 295 (4.41), 266 (4.41), 250 (4.45), 212 (4.20); IR $v_{\max }$ (liquid membrane method) $\mathrm{cm}^{-1}: 3402,2200$, 1732, 1636, 986; EI-MS m/z: $316[\mathrm{M}]^{+}$; HR-ESI-MS m/z: 339.1570 $[\mathrm{M}+\mathrm{Na}]^{+}\left(\mathrm{Calcd}\right.$ for $\left.\left[\mathrm{C}_{19} \mathrm{H}_{24} \mathrm{O}_{4}+\mathrm{Na}\right]^{+} 339.1572\right)$ ); ${ }^{1} \mathrm{H}-$ and ${ }^{13} \mathrm{C}-\mathrm{NMR}$ spectral data: see Table 1 .

Preparation of MTPA Ester $(S)$-MTPA chloride $(64.7 \mathrm{mg})$ and 3-[(dimethylamino $)$ propyl] amine $(12.2 \mathrm{mg})$ in anhydrous pyridine $(0.40 \mathrm{ml})$ was added to a solution of compound $1(20.3 \mathrm{mg})$ in $\mathrm{CHCl}_{3}(0.50 \mathrm{ml})$. After stirring at room temperature for $10 \mathrm{~h}$, the mixture was poured into water and extracted with EtOAc. The EtOAc extract was successively washed with water and saturated aqueous $\mathrm{NaHCO}_{3}$, and then evaporated off. The residue was chromatographed on silica gel $(1 \mathrm{~cm}$ i.d. $\times 5.5 \mathrm{~cm}, 2.0 \mathrm{~g})$ eluted stepwise with a mixture of acetone and benzene $(0: 100 \rightarrow 5: 95)$ to give the $(R)$-MTPA diester $\left(\mathbf{1}_{\mathbf{a}}, 12.2 \mathrm{mg}\right)$ of $\mathbf{1}$.

Compound $\mathbf{1}_{\mathrm{a}}$ : EI-MS $m / z: 748 ;{ }^{1} \mathrm{H}-\mathrm{NMR}\left(\mathrm{CDCl}_{3}\right): \delta 3.96,3.87(2 \mathrm{H}, \mathrm{m}$, $\left.\mathrm{C}_{1}-\mathrm{H}\right), 1.94\left(2 \mathrm{H}, \mathrm{m}, \mathrm{C}_{2}-\mathrm{H}\right), 5.56\left(1 \mathrm{H}, \mathrm{m}, \mathrm{C}_{3}-\mathrm{H}\right), 5.73(1 \mathrm{H}, \mathrm{dd}, J=15,6 \mathrm{~Hz}$, $\left.\mathrm{C}_{4}-\mathrm{H}\right), 6.29\left(1 \mathrm{H}, \mathrm{dd}, J=15,11 \mathrm{~Hz}, \mathrm{C}_{5}-\mathrm{H}\right), 6.60\left(1 \mathrm{H}, \mathrm{dd}, J=15,11 \mathrm{~Hz}, \mathrm{C}_{6}-\mathrm{H}\right)$, $5.65\left(1 \mathrm{H}, \mathrm{d}, J=15 \mathrm{~Hz}, \mathrm{C}_{7}-\mathrm{H}\right), 5.77\left(1 \mathrm{H}, \mathrm{dd}, J=16,1 \mathrm{~Hz}, \mathrm{C}_{12}-\mathrm{H}\right), 6.23$ $\left(1 \mathrm{H}, \mathrm{dt}, J=16,6 \mathrm{~Hz}, \mathrm{C}_{13}-\mathrm{H}\right), 4.79\left(2 \mathrm{H}, \mathrm{m}, \mathrm{C}_{14}-\mathrm{H}\right), 2.10(2 \mathrm{H}, \mathrm{d}, J=7 \mathrm{~Hz}$, $\left.\mathrm{C}_{2^{\prime}}-\mathrm{H}\right), 2.01\left(1 \mathrm{H}, \mathrm{m}, \mathrm{C}_{3^{\prime}}-\mathrm{H}\right), 0.88\left(6 \mathrm{H}, \mathrm{dd}, J=7,1 \mathrm{~Hz}, \mathrm{C}_{3^{\prime}-\mathrm{Me}}-\mathrm{H}\right), 3.48(6 \mathrm{H}$, $\left.\mathrm{m}, \mathrm{C}_{\text {MTPA-OMe }}-\mathrm{H}\right), 7.43\left(10 \mathrm{H}, \mathrm{m}, \mathrm{C}_{\text {MTPA-Ph }}-\mathrm{H}\right)$.

$(R)$-MTPA chloride $(70.1 \mathrm{mg})$ and 3 -[(dimethylamino) propyl] amine $(12.5 \mathrm{mg})$ in anhydrous pyridine $(0.36 \mathrm{ml})$ were added to a solution of compound $1(18.0 \mathrm{mg})$ in $\mathrm{CHCl}_{3}(0.50 \mathrm{ml})$. Work up as mentioned above gave the $(R)$-di-MTPA ester $\left(\mathbf{1}_{\mathbf{b}}, 25.4 \mathrm{mg}\right)$ of $\mathbf{1}$.

Compound $\mathbf{1}_{\mathrm{b}}$ : EI-MS $m / z$ : $748[\mathrm{M}]^{+} ;{ }^{1} \mathrm{H}-\mathrm{NMR}\left(\mathrm{CDCl}_{3}\right): \delta 4.03(2 \mathrm{H}, \mathrm{dd}$ $\left.J=7,6 \mathrm{~Hz}, \mathrm{C}_{1}-\mathrm{H}\right), 1.99\left(2 \mathrm{H}, \mathrm{m}, \mathrm{C}_{2}-\mathrm{H}\right), 5.52\left(1 \mathrm{H}, \mathrm{dd}, J=13,7 \mathrm{~Hz}, \mathrm{C}_{3}-\mathrm{H}\right)$, $5.62\left(1 \mathrm{H}, \mathrm{dd}, J=15,7 \mathrm{~Hz}, \mathrm{C}_{4}-\mathrm{H}\right), 6.14\left(1 \mathrm{H}, \mathrm{dd}, J=15,11 \mathrm{~Hz}, \mathrm{C}_{5}-\mathrm{H}\right), 6.55$ $\left(1 \mathrm{H}, \mathrm{dd}, J=15,11 \mathrm{~Hz}, \mathrm{C}_{6}-\mathrm{H}\right), 5.56\left(1 \mathrm{H}, \mathrm{d}, J=15 \mathrm{~Hz}, \mathrm{C}_{7}-\mathrm{H}\right), 5.77(1 \mathrm{H}, \mathrm{dd}$, $\left.J=16,1 \mathrm{~Hz}, \mathrm{C}_{12}-\mathrm{H}\right), 6.22\left(1 \mathrm{H}, \mathrm{dt}, J=16,6 \mathrm{~Hz}, \mathrm{C}_{13}-\mathrm{H}\right), 4.79\left(2 \mathrm{H}, \mathrm{m}, \mathrm{C}_{14}-\mathrm{H}\right)$, $2.11\left(2 \mathrm{H}, \mathrm{d}, J=7 \mathrm{~Hz}, \mathrm{C}_{2^{\prime}}-\mathrm{H}\right), 2.02\left(1 \mathrm{H}, \mathrm{m}, \mathrm{C}_{3^{\prime}}-\mathrm{H}\right), 0.90(6 \mathrm{H}, \mathrm{d}, J=7 \mathrm{~Hz}$,
Table 1. ${ }^{1} \mathrm{H}$ - and ${ }^{13} \mathrm{C}-\mathrm{NMR}$ Spectral Data of $\mathbf{1}$

\begin{tabular}{ccc}
\hline \hline & \multicolumn{2}{c}{$\mathbf{1}\left(\mathrm{CDCl}_{3}\right)$} \\
\cline { 2 - 3 } & \multicolumn{1}{c}{$\delta_{\mathrm{C}}$} & \multicolumn{1}{c}{$\delta_{\mathrm{H}}$} \\
\hline 1 & 60.8 & $4.14 \mathrm{~m}, 4.26 \mathrm{~m}$ \\
2 & 36.1 & $1.79-1.93 \mathrm{~m}$ \\
3 & 68.9 & $4.32 \mathrm{~m}$ \\
4 & 139.1 & $5.86 \mathrm{~d}(15)$ \\
5 & 129.2 & $6.33 \mathrm{dd}(15,11)$ \\
6 & 143.8 & $6.70 \mathrm{dd}(15,11)$ \\
7 & 110.4 & - \\
8 & 80.7 & - \\
9 & 76.6 & - \\
10 & 74.6 & $5.87 \mathrm{~d}(16)$ \\
11 & 80.8 & $6.41 \mathrm{dt}(16,5)$ \\
12 & 109.0 & $4.26 \mathrm{~m}$ \\
13 & 145.3 & $2.20 \mathrm{~d}(7)$ \\
14 & 62.7 & $2.09 \mathrm{~m}$ \\
$1^{\prime}$ & 173.5 & $0.96 \mathrm{~d}(7)$ \\
$2^{\prime}$ & 43.4 & \\
$3^{\prime}$ & 25.7 & \\
$3^{\prime}-\mathrm{CH}_{3}$ & 22.4 &
\end{tabular}

Coupling constants $(J)$ in $\mathrm{Hz}$ are given in parentheses.

$\left.\mathrm{C}_{3^{\prime}-\mathrm{Me}}-\mathrm{H}\right), 3.48\left(6 \mathrm{H}, \mathrm{m}, \mathrm{C}_{\text {MTPA-OMe }}-\mathrm{H}\right), 7.43\left(10 \mathrm{H}, \mathrm{m}, \mathrm{C}_{\text {MTPA-Ph }}-\mathrm{H}\right)$.

Hydrolysis of 1 A solution of $\mathbf{1}(2 \mathrm{mg})$ in $2 \mathrm{ml}$ of $\mathrm{MeOH}$ was added to $8 \mathrm{ml}$ of distilled water or $0.05 \mathrm{~mol} / 1 \mathrm{H}_{2} \mathrm{SO}_{4}$, and each mixture was refluxed for $1 \mathrm{~h}$. The reactants were directly subjected to HPLC analysis equipped with an ODS column (TSK GEL ODS- $80 \mathrm{~T}_{\mathrm{S}} 4.6 \mathrm{~mm}$ i.d. $\times 250 \mathrm{~mm}$, Tosoh, Tokyo, Japan). The solvents were $20 \mathrm{~mm}$ phosphoric acid (X), and acetonitrile $(\mathrm{Y})$, and a liner gradient of $90 \% \mathrm{X}$ and $10 \% \mathrm{Y}$ changing over $60 \mathrm{~min}$ to $0 \% \mathrm{X}$ and $100 \% \mathrm{Y}$ was applied. The flow rate and the column temperature were set at $1.0 \mathrm{ml} / \mathrm{min}$ and $40^{\circ} \mathrm{C}$, respectively. The UV data of effluent from the column ranging from 200 to $400 \mathrm{~nm}$ were collected. The retention times were $36.4 \mathrm{~min}$ for $\mathbf{1}$ and $20.1 \mathrm{~min}$ for hydrolysate $\mathbf{3}$.

\section{References}

1) "Japanese Pharmacopeia," 14th ed., Hirokawa Publishing Co., Tokyo, 2001, pp. D674-D677.

2) Nakai Y., Kido T., Hashimoto K., Kase Y., Sakakibara I., Higuchi M., Sasaki H., J. Ethnopharmacol., 84, 51-55 (2003).

3) Lehner M. S., Steigel A., Bauer R., Phytochemistry, 46, 1023-1028 (1997).

4) Nishikawa Y., Watanabe Y., Seto T., Yasuda I., Yakugaku Zasshi, 96, 1089-1093 (1976).

5) Kitajima J., Kamoshita A., Ishikawa T., Takano A., Fukuda T., Isoda S., Ida Y., Chem. Pharm. Bull., 51, 673-678 (2003).

6) Morita M., Sato S., Iketani Y., Mihashi H., Jpn. Kokai Tokkyo Koho, JP-04173732-A2 (1992).

7) Nishikawa Y., Yasuda I., Watanabe Y., Seto T., Yakugaku Zasshi, 96, 1322-1326 (1976)

8) Shiba M., Kondo K., Miki E., Yamaji H., Morota N., Terabayashi S., Takeda S., Sasaki H., Miyamoto K., Aburada M., Biol. Pharm. Bull., (in submission).

9) Chen Z. L., Planta Med., 53, 493-494 (1987).

10) Jente R., Bohlmann F., Schöneweiss S., Phytochemistry, 18, 829-837 (1979).

11) Dale J. A., Mosher H. S., J. Am. Chem. Soc., 95, 512-519 (1973).

12) Ohitani I., Kusumi T., Kashman Y., Kakisawa H., J. Am. Chem. Soc., 113, 4092-4096 (1991). 